\title{
ВПРОВАДЖЕННЯ ЄВРОПЕЙСЬКИХ СТРАТЕГІЙ НАВЧАННЯ СІМЕЙНИХ ЛІКАРІВ НА КАФЕДРІ СІМЕЙНОЇ МЕДИЦИНИ І ТЕРАПІЇ
}

\author{
V. M. Zhdan, M. Yu. Babanina, Ye. M. Kitura, M. V. Tkachenko \\ Ukrainian Medical Stomatological Academy, Poltava

\section{IMPLEMENTATION OF EUROPEAN TRAINING STRATEGIES OF FAMILY DOCTORS AT THE DEPARTMENT OF FAMILY MEDICINE AND THERAPY}

\begin{abstract}
Анотація. У статті представлено досвід застосування системи Body Interact - clinical reasoning education, освітньої програми віртуальних клінічних сценаріїв, яка дає можливість у реальному режимі часу відтворити певну клінічну ситуацію 3 усім необхідним сучасним набором об’єктивних, лабораторних та інструментальних методів обстеження і провести лікування відповідно до сучасних протоколів європейських та американських медичних асоціацій. Для відпрацювання техніки серцеволегеневої реанімації лікарями-інтернами ми використовуємо манекен-систему GD/ALS10 750+ALS, яка забезпечує навчання щодо підтримки життєдіяльності і дотримується рекомендацій стосовно серцево-легеневої реанімації та невідкладної допомоги при серцево-судинних захворюваннях. Використання симуляційних технологій орієнтує лікаря на командну працю, вміння враховувати точку зору іншого спеціаліста, сприяє розвитку комунікативних навичок, формуванню інтелектуальної самостійності та професіоналізму.
\end{abstract}

Ключові слова: «віртуальний пацієнт»; симуляційні технології; стандарти освіти.

Abstract. The article presents the experience of using the Body Interact - clinical education program, which enables the real time mode to recreate a certain clinical situation with all the necessary modern set of objective, laboratory and instrumental methods of examination and to conduct treatment in accordance with modern Protocols of European and American Medical Associations. For the development of the technology of cardiopulmonary resuscitation for intern we use the mannequin system GD/ALS10 750+ALS, which provides training for livelihoods and adheres to the recommendations for cardiopulmonary resuscitation and emergency care for cardiovascular diseases. Thus, the use of simulation technologies focuses a doctor on teamwork, on the ability to take into account the point of view of another specialist, promotes the development of communicative skills and the formation of intellectual autonomy and professionalism.

Key words: "virtual patient”; simulation technologies; educational standards.

Вступ. Сучасні світові стандарти в галузі освіти передбачають підготовку висококваліфікованих спеціалістів, здатних інтегрувати теоретичні знання і практичні вміння в цілісну систему, володіти новими технологіями тощо.

(c) В. М. Ждан, М. Ю. Бабаніна, Є. М. Кітура, М. В. Ткаченко
На вибір використання різних навчальних технологій у медичній освіті впливають особливості самої медичної спеціальності, в якій, безумовно, яскраво виражені як теоретична, так і практична складові. Серед найбільш частих заперечень про доцільність використання різних навчальних тех- 
нологій у медичній освіті потрібно виділити тезу про те, що ніде більше, як біля ліжка хворого, не можна визначити, чи володіє лікар необхідними знаннями, вміннями та навичками. Однак далеко не завжди і не кожен приклад можна розглянути безпосередньо «на хворому». Зокрема, це може бути пов'язано просто з відсутністю тематичних хворих під час вивчення певної теми, водночас існують активні технології і методи навчання, що дозволяють досить ефективно навчати фахівців [1, 2, 5].

Сьогодні у більшості країн світу під час підготовки медичних фахівців застосовують симуляційні технології (СТ), які $є$ новим напрямом підготовки висококваліфікованих медичних кадрів [6].

Діапазон методик, що об’єднані поняттям СТ, дуже широкий: це і різноманітні тренажери, де відпрацьовуються практичні навички з високим рівнем реалістичності, і комп’ютерні та віртуальні моделі для вдосконалення алгоритмів дій із різними клінічними ситуаціями [4].

Мета статті - підвищити ефективність підготовки лікарів-інтернів та сприяти формуванню клінічного мислення при вирішенні складних клінічних ситуацій.

Теоретична частина. Оцінка ефективності використання симуляційних методів за допомогою системи Body Interact - clinical reasoning education, освітньої програми віртуальних клінічних сценаріїв, яка дає можливість у реальному режимі часу відтворити певну клінічну ситуацію з усім необхідним сучасним набором об'єктивних, лабораторних та інструментальних методів обстеження і провести лікування відповідно до сучасних протоколів європейських та американських медичних асоціацій. Ця система використовується у більшості західноєвропейських медичних університетів, США та Канади.

Body Interact $€$ новітнім інструментом імітаційного моделювання, що призначений для використання у вищих медичних навчальних закладах та медичних коледжах для вирішення задач та клінічного обгрунтування шляхом використання віртуальних пацієнтів. «Віртуальний пацієнт» - це інноваційна інтерактивна технологія навчання, що дозволяє за допомогою комп’ютерної моделі реальної клінічної ситуації повноцінно зануритися в діагностичний i лікувальний процес, приймати самостійні рішення 3 тактики діагностики і лікування, бачити й усвідомлювати наслідки тих чи інших своїх рішень, не порушуючи при цьому прав та безпеки пацієнта. Безумовними перевагами даної технології є також стимулювання інтересу до самостійного вивчення матеріалу, наочність, можливість «взяти паузу» в процесі роботи з пацієнтів і отримати необхідну довідкову інформацію.

Це хвиля майбутнього в підготовці висококваліфікованого клініциста. Body Interact залучає до процесу інтегрованого навчання, встановлення зв'язків між концепціями і накопиченими знаннями таким чином, що інформація та навички можуть застосовуватися до нових комплексних проблем або вирішення складних задач через реальні життєві ситуації.

Сьогодні на кафедрі сімейної медицини і терапії за участю викладачів кафедри проходять навчання лікарі-інтерни з фахів «Загальна практика - сімейна медицина», «Внутрішні хвороби», «Медицина невідкладних станів», «Неврологія», «Педіатрія», «Ендокринологія». Для них є доступними 20 клінічних сценаріїв $з$ різними нозологіями, які вони опрацьовують. Такі нововведення в підготовку фахівців значно покращують як теоретичний рівень знань лікарів-інтернів, так і оволодіння практичними навичками, а загалом сприяють підвищенню якості підготовки. Все так, як у реальному житті: об’єднання всіх ресурсів та даних разом у динамічній фізіологічній моделі із десятками вбудованих станів та порушень здоров'я, лабораторних аналізів, діагностичних візуалізацій, шкали оцінки, втручання та лікування, поряд з високоефективними інструментами для підбиття підсумків. База доступних для навчання сценаріїв постійно оновлюється, забезпечуючи викладачів великою бібліотекою попередньо налаштованих клінічних сценаріїв із оновленими клінічними протоколами. Body Interact пропонує інтуїтивно зрозумілий інструмент для створення спеціальних сценаріїв, тим самим дає можливість розширити знання лікарів-інтернів та збагатити їхній досвід. 3 метою покращення якості навчання для кожного окремого інтерна або цілої групи на візуальну інформаційну панель виводиться детальний аналіз, що включає метрику дій та інтуїтивно зрозумілий інтерфейс, який значно полегшує налаштування та запуск об’ єктивно структурованих клінічних іспитів.

Наприклад, необхідно діагностувати і надати допомогу пацієнту з гострим коронарним синдромом. Про пацієнта невідомо нічого, його турбує тільки біль у грудній клітці. Ваші дії? Час іде на секунди. Будь-яка Ваша помилка може вартувати життя пацієнта. У розпорядженні лікаря знаходяться всі доступні на сьогодні методи дослідження: від фізикальних (анамнез, перкусія, аускультація) 
до найсучасніших; моніторинг показників життєдіяльності, сучасні препарати. Завдання команди або лікаря - грамотно призначити обстеження, оцінити результати дослідження, встановити діагноз, призначити лікування. Після вирішення завдання система аналізує всі дані і є можливість побачити свої результати (повнота обстеження, обгрунтованість призначення тощо).

Для відпрацювання техніки серцево-легеневої реанімації лікарями-інтернами ми використовуємо манекен-систему GD/ALS10 750+ALS. Система забезпечує навчання щодо підтримки життєдіяльності і дотримується рекомендацій стосовно серцево-легеневої реанімації та невідкладної допомоги при серцево-судинних захворюваннях, забезпечує високо реалістичну імітацію навчання діям невідкладної допомоги, що дає змогу інтернам швидко і точно освоїти стандартну роботу при невідкладній допомозі. За допомогою цієї системи імітуються також різні типи клінічних справжніх випадків [3, 4].

Навчання клінічних умінь із використанням манекенів, тренажерів і стандартизованих пацієнтів під наглядом викладача надає можливість лікарям-інтернам припускатися помилок у безпечному середовищі, що покращує опанування ними клінічних умінь. На симуляційному тренінгу пріоритетом є саме виконання навчального завдання, у процесі якого допускається негативний результат медичної допомоги, щоб той, хто навчається, відчув усю міру своєї відповідальності, але при цьому не отримав психологічної травми, яка можлива, якщо таке трапиться із справжнім пацієнтом. Симуляційне навчання виключає страх і психотравматичну компоненту від негативного результату першого досвіду стажиста, що значно покращує засвоєння навчального матеріалу.

Водночас ми, звичайно, дуже добре розуміємо, що симуляційне навчання все ж не $є$ панацеєю, в жодному разі не зможе повністю замінити навчання «біля ліжка хворого» - обидві технології в сучасному освітньому процесі повинні органічно доповнювати одна одну. У метааналітичному огляді, який був опублікований McGaghie із співавторами в 2011 р., однозначно було доведено, що симуляційне навчання повинно передувати клінічному й доповнювати його, і тоді воно дозволяє тим, Хто навчається, досягти більш високого рівня клінічної компетентності. Таким чином, перевагами симуляційних технологій є:

- клінічний досвід у віртуальному середовищі без ризику для пацієнта;

- знижений стрес під час перших самостійних маніпуляцій;

- необмежена кількість повторів для відпрацювань навичок;

- відпрацювання дій при рідкісних та таких, що загрожують життю, патологіях;

- тренінг відбувається незалежно від розкладу роботи клініки;

- частину функцій викладача бере на себе віртуальний тренажер;

- розвиток як індивідуальних умінь і навичок, так і здатності командної взаємодії;

- об’єктивна оцінка досягнутого рівня майстерHості.

Зрозуміло, що все навчання повинно проходити під чітким керівництвом і контролем викладача.

Висновки та перспективи подальших досліджень. Таким чином, використання симуляційних технологій орієнтує лікаря на командну працю, вміння враховувати точку зору іншого спеціаліста, сприяє розвитку комунікативних навичок, формуванню інтелектуальної самостійності та професіоналізму.

Надалі ми плануємо вивчити ефективність впровадження Європейських стратегій навчання сімейних лікарів на циклах тематичного удосконалення.

наук. конф. 3 міжнар. участю, 23 березня 2017 р. - Полтава, 2017. - С. 126-127.

3. Марков Ю. І. Симуляційні технології відпрацювання практичних навиків серцево-легеневої реанімації в медицині невідкладних станів / Ю. І. Марков, В. В. Орел // Медицина невідкладних станів. - 2014. - № 7 (62). С. 157-158.

4. Тутченко М. І. Симуляційні технології в навчанні студентів-медиків практичним навичкам / M. I. Тутченко, 
Я. М. Сусак // Вісник Української медичної стоматологічної академії «Актуальні проблеми сучасної медицини». - 2013. - Т. 13, вип. 1 (41). - С. 326-327.

5. Implementation of main interactive teaching methods in training of medical specialist / V. M. Zhdan, Ye. M. Kitura,

\section{References}

1. Zhdan, V.M., Babanina, M.Yu., Kitura, Ye.M., Shylkina, L.M., \& Tkachenko, M.V. (2018). Zastosuvannia innovatsiinykh tekhnolohii na kursakh pidvyshchennia kvalifikatsii likariv [Application of innovative technologies at the courses of professional development of doctors]. Visnyk problem biolohii i medytsyny - Bulletin of Biology and Medicine Problems, 4, 1(146), 142-145 [in Ukrainian].

2. Potiazhenko, M.M., Sokoliuk, N.L., \& Kitura, O.Ye. (2017). Innovatsiini tekhnolohii v orhanizatsii samostiinoi roboty likariv-interniv iz fakhu "Vnutrishni khvoroby" [Innovative technologies in the organization of independent work of doctors-interns in the specialty "Internal diseases”]. Innovatsiini tekhnolohii $v$ orhanizatsii samostiinoi roboty studentiv medychnykh osvitnikh zakladiv: Mater. navch.nauk. konf. z mizhnar. uchastiu - Innovative technologies in the organization of independent work of students of medical educational institutions: Materials of Educational Scientific Conference with International Participation. March, 23. Poltava [in Ukrainian].

3. Markov, Yu.I., \& Orel, V.V. (2014). Symuliatsiini tekhnolohii vidpratsiuvannia praktychnykh navykiv sertsevo-
M. Yu. Babanina [et al.] // Медична освіта. - 2018. № 1 (77). - C. 68-71.

6. McLeod R. Science, medicine, and the future / Rory McLeod, Robert Stone // BMJ. - 2001. - Vol. 323.

lehenevoi reanimatsii v medytsyni nevidkladnykh staniv [Simulation technologies for working out practical skills of cardiopulmonary resuscitation in emergency medicine]. Medytsyna nevidkladnykh staniv - Emergency Medicine, 7 (62), 157-158 [in Ukrainian].

4. Tutchenko, M.I., \& Susak, Ya.M. (2013). Symuliatsiini tekhnolohii v navchanni studentiv-medykiv praktychnym navychkam [Simulation technologies in teaching medical students practical skills]. Visnyk Ukrainskoi medychnoi stomatolohichnoi akademii "Aktualni problemy suchasnoi medytsyny" - Bulletin of the Ukrainian Medical Stomatological Academy "Actual Problems of Modern Medicine”, 13, 1(41), 326-327 [in Ukrainian].

5. Zhdan, V.M., Kitura, Ye.M., Babanina, M.Yu., Tkachenko, M.V., Volchenko, H.V., Shylkina, L.M., \& Lebid, V.H. (2018). Implementation of main interactive teaching methods in training of medical specialist. Medychna osvita-Medical Education, 1(77), 68-71.

6. Rory McLeod, \& Robert Stone (2001). Science, medicine, and the future. $B M J, 323$. 